\section{Scientific journal}

\section{PHYSICAL AND MATHEMATICAL EDUCATION}

Has been issued since 2013.

Науковий журнал

ФІЗИКО-МАТЕМАТИЧНА ОСВІТА

Видається з 2013.
ISSN 2413-158X (online)

ISSN 2413-1571 (print)

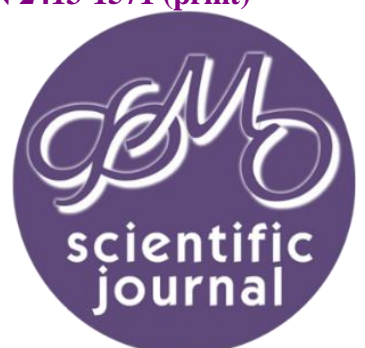

Яцура М.М., Гамарник А.М., Рачій Б.І. Методика проведення практичних занять з фізики зі студентами фізичних спеціальностей при кредитно-модульній системі організації навчання. Фізико-математична освіта. 2021. Випуск 1(27). С. 112-118.

Yatsura M., Gamarnyk A., Rachiy B. Method of conducting practical classes in physics with students of physical specialties in credit-modular system of organization of education. Physical and Mathematical Education. 2021. Issue 1(27). P. 112-118.

DOI 10.31110/2413-1571-2021-027-1-018

УДК 378.147.091.33-027.22:005.591.6:[53(076)]

М.М. Яцура

ДВНЗ «Прикарпатський національний університет імені Василя Стефраника», Україна

Yatcura1940@gmail.com

ORCID: 0000-0001-8064-6466

А.М. Гамарник

Івано-Франківського національного медичного університету, Україна gam.anna.vip@gmail.com

ORCID: 0000-0001-6443-0286

Б.І. Рачій

ДВНЗ «Прикарпатський національний університет імені Василя Стефаника, Україна

Bogdan.rachiy@pnu.edu.ua

ORCID: 0000-0001-8895-0737

\title{
МЕТОДИКА ПРОВЕДЕННЯ ПРАКТИЧНИХ ЗАНЯТЬ З ФІЗИКИ ЗІ СТУДЕНТАМИ ФІЗИЧНИХ СПЕЦІАЛЬНОСТЕЙ ПРИ КРЕДИТНО-МОДУЛЬНІЙ СИСТЕМІ ОРГАНІЗАЦІЇ НАВЧАННЯ
}

Формулювання проблеми. Перехід до кредитно-модульної системи організації навчання студентів вимагає істотного покращення проведення всіх видів навчальних занять, в тому числі і практичних робіт, а звідси виникає потреба вдосконалення методики підвищення ефективності і інтенсифікаиії проведення практичних занять, та збільшення ролі самостійної роботи студентів при цьому. Сказане засвідчує, що питання модернізації методики організації, підготовки і проведення практичних занять з фізики залишається актуальним.

Матеріали і методи. Використано багаторічний досвід авторів з організації і проведення практичних занять з фізики зі студентами фізичних спеціальностей та аналіз педагогічної, психологічної і науково- методичної літератури.

Результати. Запропоновано інноваційну методику проведення практичних занять із загального курсу фізики для студентів фізичних спеціальностей у закладах вищої освіти. Пропонується перевірку рівня теоретичних знань студентів по темі практичного заняття проводити не методом опитування і співбесіди студентів безпосередньо на практичних заняттях, як це прийнято в класичній методиці, а методом тестування. 3 цією метою підготовлено близько 2000 тестів, що дозволяє проводити тестування практично по кожному розділу навчальної програми курсу. Тестування студент повинен пройти до початку практичного заняття. Для проведення самих практичних занять створено методичні матеріали, розміщені в ЕНМКО під назвою "Матеріали до практичних занять», якими студенти мають можливість користуватися як при підготовці до практичних занять, так і при їх проведенні.

Розроблена і пропонується до використання нова форма ведення конспекту розв'язуваних на практичних заняттях задач і пояснення до них, яка на думку авторів, більш раціональна, ніж ведення конспекту в звичайному зошиті, більш зручна при користуванні нею і дає можливість студенту до кіния навчання накопичити велику кількість розв'язаних задач, які стануть в нагоді в подальшій його роботі.

Запроваджено нові форми самостійної роботи по розв'язуванню задач - че дві самостійні домашні контрольні роботи, в пакетах яких міститься близько по 70 задач, два комплекти задач (близько по 100 задач в кожному) по підготовиі до аудиторних контрольних робіт і так звані рейтингові задачі, які рекомендуються студентам для розв'язування з метою підвищення власного рейтингу впродовж семестру.

Висновки. Пропонується методика проведення практичних занять із загального курсу фрізики (розділ Оптика) для студентів фізичних спеціальностей у закладах вищої освіти.

КЛЮчОВІ СЛОВА: практичні заняття, розв'язування задач, самостійна робота, тести, тестування.

(C) М.М. Яцура, А.М. Гамарник, Б.І. Рачій, 2021. 


\section{ВСТУП}

Постановка проблеми. Однією із важливих форм ефективної підготовки майбутнього висококваліфікованого фахівця є практичні заняття, на яких викладач організовує для студентів аналіз окремих теоретичних положень навчальної дисципліни та формує уміння і навички їх практичного застосування через індивідуальне виконання відповідно сформульованих завдань (Наказ МОН України, 1993; Болюбаш, 1994).

Основним завданням практичних занять в процесі вивчення фізики $є$ відтворення, поглиблення, уточнення, закріплення та розширення теоретичних знань, набутих студентами на лекціях та в процесі самостійної роботи опісля, формування умінь та навичок аналізу й узагальнень фізичних явищ і процесів, набуття навичок і умінь застосування теоретичних знань для вирішення конкретних практичних завдань, зокрема для розв'язування фізичних задач, оскільки вміння розв'язувати задачі $€$ одним із головних критеріїв оволодіння фізикою. Тому, метою практичних занять з фізики $\epsilon$, навчити студента розв'язувати задачі. Студент в процесі розв'язування задач повинен оволодіти новими методами, накопичити певний досвід та набути стійкі уміння і навички розв'язування задач практичного характеру (Кесеманли, Коликова, 1987; Кондратьев, 2012). І саме розв'язування задач викликає найбільші труднощі у студентів.

Необхідною умовою для набуття умінь розв'язувати задачі $€$ стійкі знання теорії, однак без оволодіння спеціальними методами та прийомами i, часто без наукової інтуїції, що досягається саме на практичних заняттях, навчитися розв'язувати задачі не можливо.

Традиційну методику проведення практичних занять узагальнено (вона певною мірою різна у різних закладах вищої освіти, на різних кафедрах і в різних викладачів) можна представити так:

1. Постановка загальної проблеми (формулювання теми практичного заняття) викладачем.

2. Перевірка рівня теоретичних знань студентів по темі практичного заняття.

3. 3'ясування суті основних фізичних явищ, законів і формул, які можуть бути використані при розв'язуванні задач.

4. Розв'язування задач.

5. Оцінювання роботи студентів на практичному занятті.

6. Видача завдання для самостійного розв'язування задач вдома.

Перехід до кредитно-модульної системи організації освітнього процесу, як відомо, передбачає істотне скорочення обсягу аудиторних годин, передбачених для традиційних форм викладання, в тому числі і практичних занять, у загальному бюджеті навчального часу, зберігаючи при цьому програму навчальної дисципліни незмінною. Вище зазначене вимагає від вищої школи не просто збереження рівня підготовки фахівців з фізики, а його покращення, а звідси виникає потреба вдосконалення методики підвищення ефективності і інтенсифікації проведення практичних занять, та збільшення ролі самостійної роботи студентів при цьому. Все це засвідчує, що питання модернізації методики організації, підготовки і проведення практичних занять з фізики залишається актуальним.

Аналіз актуальних досліджень. Дослідженням основних форм навчальних занять у закладах вищої освіти, присвячені роботи Болюбаша Я.Я., Каплінського В.В., Архангельського С.І., Слободяника О.В., Мачинської Н.І. і Стельмаха С.С., Боднар А.Д., Ранської Л.А. та інших. Проблеми вдосконалення методики проведення практичних занять 3 фізики та посилення ролі самостійної роботи студентів, обговорювалися в наукових роботах Мисліцької Н.А., Кузьмінського А.І., Величко С.П., Касаманли Ф.П., Рубаника А.В., Кондратьева А.С. та ін. Однак, у більшісті із наведених наукових робіт йдеться про загальну методику проведення практичних і лабораторних занять, іноді не розділяючи їх. Наукових робіт, в яких обговорювались би конкретні методики проведення практичних занять з фізики, практично немає.

Метою статті $\epsilon$ вдосконалення методики організації, підготовки та проведення практичних занять із загального курсу фізики для студентів фізичних спеціальностей, яка 6 сприяла не тільки подальшому підвищенню інтенсифікації і ефективності проведення практичних занять, а й вихованню у студентів особистої відповідальності, самостійності та відчуття при цьому задоволення від виконаної ними роботи та власної гідності.

\section{МАТЕРІАЛИ ТА МЕТОДИ ДОСЛІДЖЕННЯ}

Складові традиційної методики організації, підготовки та проведення практичних занять за змістом, повністю збережені і в пропонованій нами методиці, за виключенням останньої: завдання для домашньої роботи студентам не пропонується, однак вони представлені в зовсім іншій формі.

В пропонованій інноваційній методиці організація, підготовка і проведення практичних занять ґрунтуються на попередньо підготовлених методичних матеріалах. Тому, першим етапом підготовки до практичних занять $\epsilon$ підготовка викладачем, який проводитиме їх, матеріалів методичного забезпечення i, не тільки практичних занять, але і вивчення всього курсу.

Нами підготовлено, на наш погляд, потужний електронний навчально-методичний комплекс із загального курсу фізики розділ «Оптика» (далі ЕНМКО), який складається із 31 розділу і, він охоплює весь спектр методичного супроводу (забезпечення) вивчення дисципліни (Яцура, Гамарник, Рачій, 2010). Матеріали ЕНМкО використовуються студентами, у всіх формах освітнього процесу вивчення дисципліни, в тому числі і при організації, підготовці та проведенні практичних занять.

Перелік тем практичних занять визначається робочою навчальною програмою і ЕНМКО. Заняття проводяться згідно розкладу, а порядок їх виконання визначається академічним календарним планом, який міститься в ЕНМКО і поуточнюється відразу після появи в електронній мережі розкладу занять. Тому студенти знають теми практичних занять і дати їх проведення із ЕНМКО.

Основним методом практичного заняття - $є$ самостійна робота, тому ефективність його проведення в першу чергу залежить від правильної організації самостійної роботи студентів. 


\section{РЕЗУЛЬТАТИ ДОСЛІДЖЕННЯ ТА ЇХ ОБГОВОРЕННЯ}

Найпершим етапом підготовки студентів до практичних занять $€$ підготовка ними теоретичного матеріалу теми практичного заняття від якості якої, як уже зазначалося вище, залежить ефективність його проведення. В пропонованій методиці перевірка рівня теоретичних знань студентів по темі практичного заняття проводиться не методом опитування співбесіди студентів на практичних заняттях, як це має місце в класичній методиці, а методом тестування. Для цієї мети авторами статті підготовлено збірник тестів з оптики (Яцура, Гасюк, Рачій, Гамарник, 2019), в якому представлено близько 2000 тестів, які охоплюють всі розділи навчальної програми курсу, що дозволяє проводити поточне тестування майже по кожному розділу навчальної програми курсу. Велика кількість тестів з кожної теми надає впевненості в об'єктивності результатів тестування. Невеликі теми (їх є декілька) об'єднуються і розглядаються на практичних заняттях разом. Наприклад, теми: ефект Комптона, тиск світла і корпускулярні властивості світла, розглядаються на одному практичному занятті і тестування, відповідно, проводиться також разом зі всіх трьох тем. 3 тестами будь-якої теми студент має можливість ознайомитися заздалегідь, оскільки збірник тестів в електронній формі знаходиться у вільному доступі на сайтах наукової бібліотеки і кафедри матеріалознавства і новітніх технологій Прикарпатського національного університету імені Василя Стефаника. Ці ж тести використовуються для здачі студентами двох змістовних теоретичних модулів та проведення підсумкового контролю знань (екзамену). Методика проведення тестування викладена в передмові до збірника тестів та уточнена в (Яцура, Гамарник, Рачій, 2019).

Студент напередодні (можна і раніше) проведення практичного заняття, повинен увійти в електронну мережу, вибрати тему найближчого за розкладом практичного заняття i, протестуватися. Це він може зробити у зручний для нього час і в зручному місці (в навчальній лабораторії, в комп'ютерному класі, вдома). Тестування є обов'язковим і студент повинен його пройти до проведення практичного заняття. Результат тестування студента (відсотки правильних відповідей) виставляється в спеціальну відомість, яка зберігається в програмі лабораторного комп'ютера.

Перед початком практичних занять викладач перевіряє по комп'ютеру результати тестування. Якщо студент проігнорував тестування, викладач напроти прізвища даного студента виставляє цифру -20\%. Це штрафні відсотки, які будуть вирахувані від результату майбутнього тестування. Якщо ж напроти прізвища студента стоїть цифра <25\%, викладач, поряд з цією цифрою виставляє цифру $-10 \%$, яка також $є$ штрафною і також буде вирахувана від результату наступного тестування студента. В кінці семестру результати тестування у відсотках переведеться в бали і враховуються при виставленні рейтингової оцінки.

Для проведення самих практичних занять в ЕНМКО створено розділ під назвою «Матеріали до практичних занять». Тут викладено методичні матеріали, якими як викладач, так і студенти користуються при підготовці до практичних занять та при ї проведенні, але вони розраховані більше на студента а ніж на викладача.

На початку занять викладач формулює тему практичного заняття, яка разом з питаннями, котрі повинні бути розглянуті на занятті, проектується на екран, розміщений поряд з аудиторною дошкою. Опісля на екран проектується набір основних фізичних понять (своєрідний глосарій), якими студенти користуватимуться при обговоренні природи оптичних явищ. По цьому на екрані появляються формули, які необхідні будуть при розв'язуванні задач а, за ними йдуть кілька теоретичних запитань, суть яких студенти з'ясовують (при потребі) разом з викладачем. Цю частину практичного заняття студенти називають «розминкою». При цьому викладач слідкує, щоб в обговоренні питань приймали участь всі студенти. Активність студентів під час «розминки» і правильність міркувань при обговоренні питань, враховується викладачем при оцінці роботи студента на практичному занятті.

За розминкою на екран проектується умова задачі, яку студенти повинні розв'язати в аудиторії. Якщо рисунок, необхідний для розв'язку задачі, складний і, студенти відчувають труднощі в його побудові, то він також проектується на екран. Після ознайомлення студентів з умовою задачі і рисунком, до дошки виходить студент і, якщо він успішно справився із задачею, на екран проектується хід розв'язку задачі для порівняння правильності розв'язку на дошці. Якщо ж студент відчуває труднощі при розв'язуванні задачі, то на екран проектується підказка. Таких підказок може бути декілька (в залежності від складності задачі) i, вони можуть мати місце до тих пір, поки задача не буде розв'язана.

Подібним чином студенти розв'язують декілька задач, при цьому, по можливості, задачі стають складнішими, після чого для розв'язку пропонуються типові задачі без будь-яких підказок, умови яких також проектуються на екран.

Якщо із отриманої робочої формули для розрахунку шуканої фізичної величини задачі явно не витікає ї̈ одиниця вимірювання, то викладач обов'язково ставить перед студентами завдання: користуючись робочою формулою знайти одиницю вимірювання шуканої фізичної величини. Наприклад, при знаходженні амплітудних значень напруженості електричного і магнітного полів світлової хвилі в одній із задач були отримані робочі формули:

$$
E_{0}=\sqrt{\frac{2\langle S\rangle}{c \varepsilon_{0}}} \mathrm{i} H_{0}=\sqrt{\frac{2\langle S\rangle}{c \mu_{0}}}
$$

із, яких явно не видно, що одиницею вимірювання $E_{0} \in B / M$, а $H_{0}-A / M$. Ïх потрібно студентам знайти самим i, коли студенти затрудняються це зробити самостійно, їм на допомогу приходить підказка:

$$
\begin{aligned}
& {\left[E_{0}\right]=\left[\sqrt{\frac{B T}{M^{2} \cdot \frac{M}{C} \cdot \frac{\Phi}{M}}}\right]=\left[\sqrt{\frac{A \cdot B \cdot C}{M^{2} \cdot \frac{K M}{B}}}\right]=\left[\sqrt{\frac{A \cdot B \cdot C \cdot C}{M^{2} \cdot \frac{A \cdot C}{B}}}\right]=\left[\sqrt{\frac{B^{2}}{M^{2}}}\right]=\left[\frac{B}{M}\right],} \\
& {\left[H_{0}\right]=\left[\sqrt{\frac{B T}{M^{2} \cdot \frac{M}{c} \cdot \frac{\Gamma H}{M}}}\right]=\left[\sqrt{\frac{A \cdot B \cdot C}{M^{2} \cdot \frac{B \cdot C}{B}}}\right]=\left[\sqrt{\frac{A^{2}}{M^{2}}}\right]=\left[\frac{A}{M}\right],}
\end{aligned}
$$

де $[S]=\left[\frac{\mathrm{BT}}{\mathrm{M}^{2}}\right],\left[\varepsilon_{0}\right]=\left[\frac{\Phi}{\mathrm{M}}\right],\left[\mu_{0}\right]=\left[\frac{\Gamma \mathrm{H}}{\mathrm{M}}\right], 1 \mathrm{BT}=1 \mathrm{~A} \cdot 1 \mathrm{~B}, 1 \Phi=\frac{1 К л}{1 \mathrm{~B}}, 1$ Кл $=1 \mathrm{~A} \cdot 1 \mathrm{c}, 1 \Gamma_{\mathrm{H}}=\frac{1 \mathrm{~B} \cdot 1 \mathrm{c}}{1 \mathrm{~A}}$

При потребі викладач допомагає студентам осягнути зміст підказки.

Якщо тема, яка виноситься на практичні заняття об'ємна (наприклад, дифракція чи поляризація світла), то вона, згідно тематики (плану) практичних занять, розбивається на два або навіть три заняття. На допомогу студенту підготовлені 
методичні поради, щодо розв'язування задач з оптики, які викладені в посібнику (Остафійчук, Яцура, Яремій, Гамарник, 2016), електронна версія якого розміщена в ЕНМко.

По закінченню практичного заняття викладач підводить підсумки і оцінює роботу студентів на практичному занятті. Оцінки, отримані студентом за окремі практичні заняття та тестування, виставляються в академічний журнал і зараховуються при виставленні підсумкової оцінки.

Домашніх завдань, тобто задач для розв'язування вдома, як це має місце в класичній методиці, студентам не пропонується. Натомість в ЕНМКО наведено два комплекти задач під назвою «Задачі для домашніх контрольних робіт № 1 і № 2. Перша робота виконується після вивчення перших п'яти тем, друга - після вивчення всіх інших. В кожній із домашніх контрольних робіт студент повинен розв'язати біля 70 задач, оформити їх відповідним чином (в письмовому або електронному вигляді) і здати викладачеві (переслати на електронну адресу викладача) в певні терміни, згідно академічного календаря вивчення дисципліни, для перевірки. Викладач перевіряє роботу, оцінює їі і повертає студенту. Кожна робота оцінюється максимально в п'ять балів. На допомогу студенту розроблені і поміщені в ЕНМкО «Методичні вказівки щодо виконання і оформлення домашніх контрольних робіт». Досвід свідчить, що студенти перевагу віддають дистанційному зарахуванню домашніх контрольних робіт.

Органічною складовою практичних занять $€$ аудиторні контрольні роботи, які виконують не тільки контрольнооціночну функцію (як дехто із викладачів вищої школи вважає), але і пізнавальну функцію та функцію вдосконалення умінь і навичок застосування теоретичних знань для розв'язування фізичних задач. Змістом аудиторних контрольних робіт $\epsilon$ розв'язування певної кількості спеціально підібраних задач. Відповідно до академічного календаря вивчення оптики, студенти протягом семестру повинні виконати дві аудиторні контрольні роботи.

Задачі для контрольних робіт, перша із яких проводиться після вивчення перших п'яти тем, друга - після вивчення всіх інших, наведені в ЕНМКО. Із великої кількості наведених задач (в кожному наборі близько 100 задач), до яких студенти мають вільний доступ, формуються завдання для контрольних робіт. Кожне завдання складається із п'яти задач різних тем, які для кожного студента вибирає комп'ютер. Робота виконується протягом 120 хв.

Вільний доступ до задач, з яких формуються завдання для контрольних робіт, дає можливість студенту не тільки ознайомитися з ними, але і розв'язати їх, що позитивно впливає на результати контрольних випробувань. Методичні поради щодо виконання і оформлення контрольних робіт розміщено в ЕНМКО. Контрольна робота оцінюється максимум в 7 балів.

Особливою частиною практичної роботи студентів, є самостійне розв'язування так званих «рейтингових задач», які рекомендуються студентам для розв'язування з метою підвищення власного рейтингу впродовж семестру. Це задачі підвищеної складності і студенти розв'язують їх на добровільній основі. За кожну розв'язану рейтингову задачу студент отримує певну кількість балів (задача оцінюється в залежності від їі складності, а кількість балів вказані в кінці умов задач, розміщених в ЕНМКО).

Вибравши задачу, студент повинен розв'язати ії, розв'язок належним чином (письмово або в електронному вигляді) оформити (пояснення, рисунки, малюнки тощо), здати викладачеві для ознайомлення з ним і захистити на одному із практичних занять з використанням презентацій. При оцінці роботи враховуються знання теоретичного матеріалу з яким зв'язана задача, розуміння логіки розв'язку, результати розрахунків, якщо задача розрахункова, оформлення роботи, вміння усно доповідати матеріали, отримані при розв'язанні задачі та якість презентаційного супроводу.

Наприклад, студент вибрав серед великої кількості рейтингових задач (рейтингові задачі (їх $є$ біля 100), як $\mathrm{i}$ методичні поради щодо їх розв'язання та умов захисту, розміщені в ЕНМКО) задачу: Точно над олівцем, розміщеним вертикально над водою, знаходиться точкове джерело світла. На дні посудини з водою видно тінь від олівия. Якщо олівець опускати поволі у воду, то розмір темної плями (тіні) збільшується. Якщо потім олівець виймати поволі з води, то на місці темної плями появляється світла. Пояснити описане явище (3б).

Розв'язавши цю задачу і вдало захистивши їі розв'язання студент може отримати додаткові 3 бали.

Проаналізувавши умову задачі студент зрозумів, що для їі розв'язування потрібно володіти не тільки теоретичними знаннями з оптики, але і з молекулярної фізики - поверхнева енергія, поверхневий натяг, капілярні явища. Далі він дійшов висновку, що внаслідок зчеплення молекул води і поверхні олівця, коли олівець опускати у воду, біля поверхні олівця утворюється випукла поверхня води, яка виконує роль розсіювальної лінзи - промені від джерела світла, відхиляються від осі олівця і під олівцем утворюється велика темна пляма (рис. 1). Коли олівець витягати із води, біля поверхні олівця утворюється вгнута поверхня води, яка виконує роль збиральної лінзи - промені від джерела світла нахиляються до осі олівця і під олівцем утворюється світла пляма (рис. 2). Студент розв'язав задачу правильно, оформив її відповідно і успішно захистив роботу, при цьому не тільки заробив 3 бали, але що не менш важливо, залишився задоволеним від виконаної ним роботи.

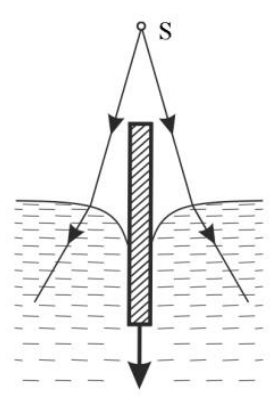

Рис. 1

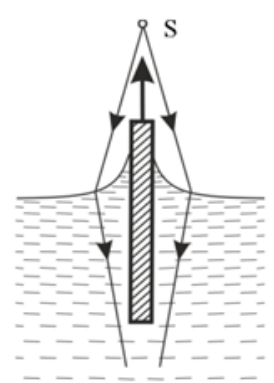

Рис. 2 
Оцінки (в балах), отриманих за розв'язування рейтингових задач, виставляються в академічний журнал, і при підсумковому контролі знань додаються до загальної кількості балів студента при виставленні підсумкової оцінки. Практика показує, що кількість студентів, які бажають розв'язувати «рейтингові задачі» зростає.

Далеко не останню роль в проведенні практичних занять відіграє запис студентом розв'язаних задач і іншої інформації, яку він отримує на практичних заняттях (ведення конспекту практичних занять). Цьому питанню ані науковціпедагоги, ані науковці-методисти не надають належної уваги.

Сьогодні розв'язання задач і пояснення до них, студенти, як правило, записують в зошитах, дехто на окремих аркушах паперу, а дехто і взагалі не записує, сподіваючись на свою пам'ять. Не дивлячись на те, що методика ведення конспекту в зошиті $€$ загально прийнятою, автори статті вважають ії не ефективною. У добросовісного студента зошит з часом швидко «розбухає» за рахунок вставок додаткових аркушів паперу з новими задачами, з різною додатковою інформацією тощо. Таким «конспектом» незручно користуватися, як при пошуку інформації в ньому, так і при підготовці до контрольних робіт, змістових практичних модулів, до підсумкового контролю знань (екзамену). Виходячи із зазначеного, ми пропонуємо відмовитися від класичної форми запису розв'язку задач у звичайному зошиті, і замінити його записом розв'язання задач на окремих аркушах паперу.

Цупкий стандартних розмірів аркуш паперу (будь-якого кольору, окрім чорного) розрізається по довжині навпіл і на цих картках і пропонується вести конспект розв'язаних задач і їх пояснень. На окремій вкладці (бажано їі виготовити із тонкого картону) перед першою карткою записується тема практичного заняття. Наприклад: Тема 1-а. Основні властивості світла. Після вкладки йде перша картка на першій сторінці якої записується: Задача 1.1 (де перша цифра є номер теми, друга - номер задачі), умова задачі і її розв'язання з поясненнями. Після отримання робочої формули далі записуються вивід одиниці вимірювання шуканої фізичної величини і числові обрахунки. Якщо є якісь дані, які використані при розв'язанні задачі і вони можуть з часом стертися з пам'яті, то про них на картці також варто вказати. Зворотну сторінку картки варто залишати чистою, можливо з часом на ній буде поміщено розв'язання іншої задачі цієї ж теми або якісь доповнення, свої висновки до задачі розв'язаної на попередній сторінці.

Наступна задача і її розв'язання записується на наступній картці (наприклад, Задача 1.2, Задача 1.3 і т. д). Сторінки карток також бажано нумерувати. Далі буде 2-а тема (Задача 2.1, Задача 2.2 і т. д.), 3-я ... і, коли накопичиться чи мало карток із задачами, необхідно виготовити невеликий ящик по ширині картки, подібний до бібліографічного ящика в бібліотеці, і в порядку тем курсу і номерів задач розмістити в ньому картки. Щоправда, тут є один недолік - ящик незручно носити з собою до місця навчання, однак, якщо якась частина задач потрібна для роботи в аудиторії, наприклад, на практичних заняттях, то картки певної теми не важко вилучити із ящика, а опісля помістити їх на своє місце. В процесі навчання, якщо студент знайшов цікаву задачу, то він ії, і ії розв' язання з поясненнями, запише на чистій зворотній сторінці однієї із карток відповідної теми (або на новій картці) і позначить ії, наприклад, «Задача 1.За» і вкладе ї̈ на відповідне місце теми, якій відповідає задача.

При підготовці до контрольної роботи, змістового практичного модуля чи до якогось іншого контрольного заходу, студент вилучає із ящика задачі відповідної теми, розкладає їх на робочому столі і опрацьовує кожну задачу. При цьому йому не потрібно гортати сторінки зошита вперед-назад, а навпаки, він може вільно розглядати одну за одною задачі, порівнювати їх, вносити в них доповнення, або зміни при потребі, виписувати необхідну інформацію. Закінчивши роботу із задачами однієї теми, студент так само продовжує працювати із задачами наступної теми, розмістивши задачі попередньої теми на своє місце в ящику і т. д.

Якщо студент розпочне в такий спосіб «конспектувати» практичні заняття з першого курсу, то при закінченні вивчення загального курсу фізики його ящик буде містити більше 1000 розв'язаних задач і їх поясненнями, що стане великим надбанням студента.

Окрім вище викладеного, при організації і проведенні практичних робіт слід враховувати і такі особливості.

1. При підборі для розв'язування студентами задач, чи це аудиторно, чи самостійно, необхідно враховувати, що задачі з фізики бувають двох видів: задачі на засвоєння навчального матеріалу і задачі на активне використання вивченого матеріалу. Задачі першого виду називають стандартними, алгоритми розв'язання для більшості із яких часто описуються в самих збірниках задач, інші аналізуються викладачами на заняттях. Особливих труднощів, при розв'язуванні таких задач, як правило, у студентів не виникає, оскільки саме при розв'язуванні стандартних задач відбувається перевід знань, засвоєних на рівні відтворення, на рівень знань-умінь, але розв'язування таких задач нових знань не додають.

Задачі на активне використання вивченого матеріалу часто називають нестандартними, проблемними, пошуковими, творчими. Такі задачі вимагають від студента творчого підходу до їх розв'язання, самостійного пошуку методу і способу розв'язання задачі, прояву кмітливості, інтуїції і великої напруги розумових здібностей. Навіть у найбільш підготовлених студентів розв' язання цього виду задач іноді викликає певні труднощі. Про те, розв'язування нестандартних (творчих) задач розвиває у студентів здатність аналізувати фізичні явища, знаходити в них спільності і відмінності, встановлювати причинно-наслідкові зв'язки, співставляти експериментальні факти з теоретичними передумовами, тобто розвиває наукове мислення. Спираючись на зазначене зрозуміло, що саме другому виду фізичних задач потрібно надавати перевагу, хоча упускати з уваги перший вид задач (стандартні задачі) також не слід.

2. Сьогодні, як уже зазначалось вище, обсяг аудиторних навчальних годин, передбачених для традиційних форм викладання дисциплін, в тому числі і практичних занять, у загальному бюджеті навчального часу різко скоротився, внаслідок чого частина задач, які пропонуються студентам для самостійного розв'язування, відноситься до не розглядуваного на навчальних заняттях (лекціях) матеріалу, а частина - до уже розглядуваного на навчальних заняттях матеріалу. При організації самостійного розв'язування задач, зазначене слід враховувати.

3. За останні роки в заклади вищої освіти на фізичні спеціальності приходять випускники шкіл з явно неоднаковим рівнем фізико-математичної підготовки. Іноді ця різниця суттєва і не враховувати їі при організації і проведенні практичних занять зі студентами було 6 не правильно. Однак слід визнати, що це не завжди вдається, особливо якщо студентська 
група велика (>15 студентів). Тут очевидно мова повинна йти про максимальну індивідуалізацію навчальної роботи студентів в цілому.

4. На практичних заняттях студенти повинні дотримуватися принципу максимальної самостійності. Умови, щоб всі види робіт (тестування до кожного практичного заняття, розв'язування задач в аудиторії, виконання домашніх контрольних робіт, виконання аудиторних контрольних робіт та розв'язування рейтингових задач) виконувалися самостійно, повинен створити викладач, який проводить практичні заняття,

5. Ефективність практичних занять залежить не тільки від теоретичної підготовки студентів, від ї ініціативи і активності на практичних заняттях, але і від оцінювання їхньої роботи викладачем. Студент повинен бути переконаним, що його робота буде оцінена об'єктивно, без будь-яких скидок і натяжок. Для цього повинні бути розроблені чіткі критерії оцінювання знань студентів зі всіх видів робіт, в тому числі і практичних і, студент повинен бути з ними ознайомлений. Такі критерії нами розроблені, і вони містяться у вигляді спеціальної таблиці в ЕНМКО, а оцінки, за кожний вид роботи, виставляються у відомість контролю знань поетапно, яка також міститься ЕНМКО.

\section{висновки}

Запропоновано інноваційну методику проведення практичних занять із загального курсу фізики для студентів фізичних спеціальностей у закладах вищої освіти, основними положеннями якої є:

1. Перевірка рівня теоретичних знань студентів по темі практичного заняття проводиться не методом опитування і співбесіди студентів на практичних заняттях, як це прийнято в класичній методиці, а методом тестування. Причому тестування студент повинен пройти до початку практичного заняття.

2. Практичні заняття проводяться з використанням спеціально розроблених методичних матеріалів, об'єднаних в ЕНМК, і сучасних комп'ютерних технологій.

3. Нова форма ведення запису розв'язуваних на практичних заняттях задач і пояснення до них (конспект практичних занять), яка на думку авторів статті $€$ більш раціональна ніж ведення таких записів у звичайному зошиті.

4. Нові форми організації самостійної роботи по розв'язуванню задач - це дві самостійні домашні контрольні роботи, два комплекти задач по підготовці до аудиторних контрольних робіт і так звані рейтингові задачі.

Подальші дослідження будуть пов'язані із вдосконаленням методики різних форм навчальних занять в тому числі і практичних занять.

\section{Список використаних джерел}

1. Положення «Про організацію навчального процесу у вищих навчальних закладах». Наказ МОН України № 161 від 02.06. 1993 p. zakon.rada.gov.ua>z0173-93

2. Болюбаш Я.Я. Організація навчального процесу у вищих закладах освіти. Навч. посібник. Київ: ВВП «Компас», 1997. 64 c. .

3. Самостоятельная работа студентов при решении задач по физике: методические указания. Сост. Ф.П. Кесаманлы, В.М. Коликова. Л: 1987. 32 с.

4. Яцура, М.М., Гамарник, А.М., Рачій Б.І. Навчально-методичний комплекс 3 оптики (НМкО). http://lib.pnu.edu.ua/read.php?id=9787

5. Яцура М.М., Гасюк І.М., Рачій Б.М., Гамарник А.М. Курс загальної фізики. Оптика. Тести: навчально-методичний посібник. Івано-Франківськ: Видавництво ДВНЗ «Прикарпатський національний університет імені Василя Стефаника», 2019. $382 \mathrm{c}$.

6. Яцура М.М., Гамарник А.М., Рачій Б.І. Про вдосконалення тестового контролю знань студентів з фізики. Освітній простір Україниб, 2019. Вип. 17. С. 102-106.

7. Остафійчук Б.К., Яцура М.М., Яремій І.П., Гамарник А.М. Практикум розв'язування задач з курсу загальної фізики. Оптика (друге видання, перероблене і доповнене). Івано-Франківськ: ДВНЗ «Прикарпатський національний університет імені Василя Стефаника», 2016. 365 с.

8. Кондратьев А.С., Ларченкова Л.А., Ляпцев А.В. Методы решения задач по физике. М: ФИзМАТЛИТ, 2012. 312 с.

\section{References}

1. Polozhennia «Pro orhanizatsiiu navchal'noho protsesy y vyshchykh navchal'nykh zakladakh» [Regulations "On the organization of the educational process in higher educational institutions"]. Nakaz MON Ukrayny №161 vid 02.06.1993 p. zakon.rada.gov.ua>z0173-93 [in Ukrainian].

2. Bolyubash Ya.Ya. (1997). Orhanizatsiya navchal'noho protsesu u vyshchykh zakladakh osvity [Organization of the educational process in higher educational institutions]. Navch. posibnyk. Kyiv: VVP «Kompas» [in Ukrainian].

3. Samostoiatel'naia rabota studentov pri reshenii zadach po fizike: metodicheskiye ukazaniya [Independent work of students in solving problems in physics: guidelines]. Sost. F.P. Kesamanly, V.M. Kolikova. - L: (1987) [in Ukrainian].

4. Yatsura M.M., Gamarnyk A.M., Rachiy B.I. (2019). Navchal'no-metodychnyy kompleks z optyky (NMKO) [Educational and methodical complex on optics (NMKO)]. http://lib.pnu.edu.ua/read.php?id=9787 [in Ukrainian].

5. Yatsura M.M., Hasyuk I.M., Rachiy B.M., Gamarnyk A.M. (2019). Kurs za zahal'noyi fizyky. Optyka. Testy [Course in general physics. Optics. Tests]. Ivano-Frankivs'k: DVNZ «Prykarpat·s'kyy natsional'nyy universytet imeni Vasylia Stefanyka» [in Ukrainian].

6. Yatsura M.M., Gamarnyk A.M., Rachiy B.I. (2019). Pro vdoskonalennia testovoho kontroliu znan' studentiv z fizyky [About improvement of test control of knowledge of students in physics]. Osvitniy prostir Ukrayiny. Вип. 17. С 102-106. [in Ukrainian].

7. Ostafiychuk B.K., Yatsura M.M., Yaremiy I.P., Gamarnyk A.M. (2016). Praktykum roz-v"yazuvannia zadach z kursu zahal'noy fizyky. Optyka (druhe vydannya, pe-reroblene i dopovnene) [Workshop for solving problems in the course of general physics. 
Optics (second edition, revised and supplemented)]. Ivano-Frankivs'k: DVNZ «Prykarpat·s'kyy natsional'nyy universytet imeni Vasylia Stefanyka» [in Ukrainian].

8. Kondrateva A.S., Larchenkova L.A., Liaptsev A.V. (2012). Metody resheniia zadach po fizike [Methods for solving problems in physics.] M.: FIZMATLIT [in Russifn].

\author{
METHOD OF CONDUCTING PRACTICAL CLASSES IN PHYSICS WITH STUDENTS OF PHYSICAL SPECIALTIES \\ IN CREDIT-MODULAR SYSTEM OF ORGANIZATION OF EDUCATION \\ Mykhailo Yatsura \\ Vasyl Stefanyk Precarpathian National University Ukraine \\ Anna Gamarnyk \\ Ivano-Frankivsk National Medical University, Ukraine. \\ Bohdan Rachiy \\ Vasyl Stefanyk Precarpathian National University Ukraine
}

Abstract.

Problem formulation. The transition to a credit-module system of student education requires a significant improvement in all types of classes, including practical work, and hence the need to improve the methodology of improving the efficiency and intensification of practical classes, and increasing the role of independent work of students in this. This shows that the issue of modernization of methods of organization, preparation and conduct of practical classes in physics remains relevant.

Materials and methods. The long-term experience of the authors in organizing and conducting practical classes in physics with students of physical specialties and analysis of pedagogical, psychological and scientific-methodical literature is used.

Results. An innovative method of conducting practical classes in the general course of physics for students of physical specialties in higher education institutions is proposed. It is proposed to check the level of theoretical knowledge of students on this topic by testing, rather than by interviewing students, as is customary in the classical method. For this purpose, about 2,000 tests have been prepared, which allows testing in almost every section of the curriculum. The student must take the test before the start of the practical lesson. For conducting practical classes methodical materials are created, which are placed in EEMCO under the name "Materials for practical classes". Students have the opportunity to use them, both in preparation for practical classes and in their conduct.

A new form of keeping a synopsis of the problems solved in practical classes and an explanation to them has been developed and proposed for use, which, in the opinion of the authors, is more rational than keeping a synopsis in an ordinary notebook. This form is more convenient to use and allows the student to accumulate a large number of solved problems by the end of the study, which will be useful in his further work. New forms of independent work on solving problems have been introduced-these are two independent home control works, which contain about 70 tasks, two sets of tasks (about 100 tasks in each) to prepare for classroom tests and socalled rating tasks, which are recommended for students to solve in order to increase their own rating during the semester.

Conclusions. The method of conducting practical classes on the general course of physics (section Optics) for students of physical specialties in higher education institutions is offered

Keywords. practical classes, problem solving, independent work, tests, testing.

\title{
(c) BY-NC-SA
}

This work is licensed under Creative Commons Attribution-NonCommercial-ShareAlike 4.0 International License. 